\title{
HAEMATOLOGY PROFILE OF FRUIT BATS Cynopterus spp. FROM SPECIAL REGION YOGYAKARTA, INDONESIA
}

\author{
HUSNI MUBAROK ${ }^{1 *}$, NIKEN SATUTI NUR HANDAYANI ${ }^{1}$, \\ TUTY ARISURYANTI ${ }^{1}$ and IBNU MARYANTO ${ }^{2}$ \\ ${ }^{1}$ Department of Tropical Biology, Biology Faculty, Universitas Gadjah Mada, Yogyakarta, \\ Jl. Teknika Selatan, Sekip Utara 55281 Yogyakarta, Indonesia \\ ${ }^{2}$ Museum Zoologicum Bogoriense, Widyasatwaloka Building, Research Centre in Biology - LIPI, \\ Jl. Raya Cibinong KM 46 Cibinong Indonesia \\ *E-mail: husnimubarok88@mail.ugm.ac.id
}

Accepted 12 March 2021, Published online 20 May 2021

\begin{abstract}
Cynopterus spp. is a fruit bats genus that is widely distributed in Asia and plays an important role as pollinator and seed disperser of plants in different habitats. Haematological data is affected by sex, age, and external factors. It is also needed in examination of the health conditions, body defenses, and physiological conditions of bats. Complete haematological data of this genus in Indonesia remain a lack of information. This study aimed to analyze the haematological profile of Cynopterus spp. Bats were captured using mist nets at three different habitat types in the special region of Yogyakarta, Indonesia. Total 31 individuals from four species Cynopterus spp. were trapped. Blood samples were collected from the intracardiac. 20 parameters including the density of erythrocyte, leukocyte, and platelet profiles were analyzed. The result indicated red cell distribution width standard deviation counts between juvenile and adult, leukocyte number and platelet number between urban and non-urban of $C$. brachyotis were significantly different. Those results are presumed to be associated with age stage and environmental conditions. A large number of fruit bats individuals from different habitat is necessary for further study.
\end{abstract}

Key words: Bats, Cynopterus brachyotis, erythrocyte, haematological data

\section{INTRODUCTION}

Cynopterus spp. is fruit bats that belong to the family Pteropodidae, order Chiroptera, and widely distributed in Asia. Seven species of Cynopterus inhabit Indonesia, namely Cynopterus brachyotis, C. titthaecheilus, C. sphinx, C. luzoniensis, C. nusatenggara, C. horsfieldii and C. minutus (Simmons \& Cirranello, 2020; Burgin et al., 2020). Furthermore, C. brachyotis, C. sphinx and $C$. horsfieldi has been distributed and shared sympatry area in the Indochinese Peninsula, Borneo, Sumatra, Java, and India (Campbell et al., 2004).

Species in the Cynopterus spp. genus has an important role as seed disperser and pollinator in the ecosystem. Several studies show that $C$. brachyotis is known to pollinate for at least 16 plant species in the secondary forest or fragmented area. While, about 14 plant species in the area between

* To whom correspondence should be addressed. primary and secondary forests at lower elevations are pollinated by $C$. tittacheilus (Mickleburgh et al., 1992; Maryanto, 1993; Maryati et al., 2008; Soegiharto et al., 2010). Cynopterus brachyotis is also well known as eurytopic species, a species that have foraging in diverse habitats, including the urban area, orchard, secondary and primary forests to mangroves and tolerate its environmental conditions (Kartono et al., 2017).

Blood is a very important component of the physiological process of animals. Parameters in the haematological profile can be used for detecting health status (including genetic diseases), nutrition, stress levels, and determining protection status and management of animal population (Hossain et al., 2013; Hall et al., 2014; McMichael et al., 2015; Saimina et al., 2019). For example, the results obtained from different parameters included in the erythrocyte profile can give information related to different aspects of metabolism and immunity, such as oxygen binding for energy requirements in the 
metabolic process. It is also associated with the activity and stress levels of an animal (Fitria \& Sarto, 2014).

Also, blood profile analysis can be used as a normal reference range for further study and pathological condition references (Gulland \& Hawkey, 1990). Sex, age, environmental condition, and stress level are factors that may affect the haematological profile of animals, including bats (Ekeolu \& Adebiyi, 2018). The current haematological study of species that belongs to Cynopterus spp. in Indonesia has been poorly known (Wijayanti et al., 2011; Rahma et al., 2017; Saimina et al., 2019). Moreover, since Cynopterus spp. is known as widespread fruit bats and tolerant to different habitats, it is interesting to investigate a complete haematology profile that is compared by sex, age, and habitat types, also stress levels of this species. This study aims to analyze the haematological profile of species Cynopterus spp. based on sex, age, and urban-non-urban category.

\section{MATERIALS AND METHODS}

\section{Research location and study area}

This study was conducted in three sampling sites with different habitat and altitude, including Bulaksumur urban area, Sleman district ( $7^{\circ} 45^{\prime} 57.2^{\prime \prime}$ $\mathrm{S}, 110^{\circ} 22^{\prime} 32.8^{\prime \prime} \mathrm{E} ; 153 \mathrm{~m}$ above sea level; $1.83 \mathrm{~km}^{2}$ ),
Tlogo Nirmolo primary forest, Merapi volcano national park (7³5’24.2" S, 110²5’35 .7" E; 1129 m above sea level; $4.62 \mathrm{~km}^{2}$ ) and Wanatirta mangrove forest (7॰53'32.9" S, 11001'10.1" E; $6 \mathrm{~m}$ above sea level; $0.08 \mathrm{~km}^{2}$ ) of Yogyakarta region, Indonesia from November to December 2019 (Figure 1). The special region of Yogyakarta is a tropical area with an average annual temperature of about $25.1{ }^{\circ} \mathrm{C}$ and precipitation of about $2681 \mathrm{~mm}$ per year.

\section{Sampling and identification}

Bats were captured using $6 \mathrm{~m} \times 2.5 \mathrm{~m}$ mist nets (Shijiazhuang Xiaoxuan Co., LTD) at each sampling location. Mist nets were placed 2 - 3 meters above the ground near potential fruit trees that were visited by bats. All individuals of Cynopterus spp. that trapped in mist nets were handled carefully and put in a canvas bag. Bats were carried to the Laboratory of Animal Physiology, Biology Faculty Universitas Gadjah Mada, Yogyakarta for haematology analysis. Species identification was based on the key identification of Suyanto (2001) and Huang et al. (2016). Sex determination (male and female), age category (adult and juvenile), reproductive status (lactating, post-lactating, or pregnant), six external morphological measurements, and also body weight were also done. The average temperature and humidity of each sampling location were also measured using a digital Thermo-hygrometer (Benetech GM1361).

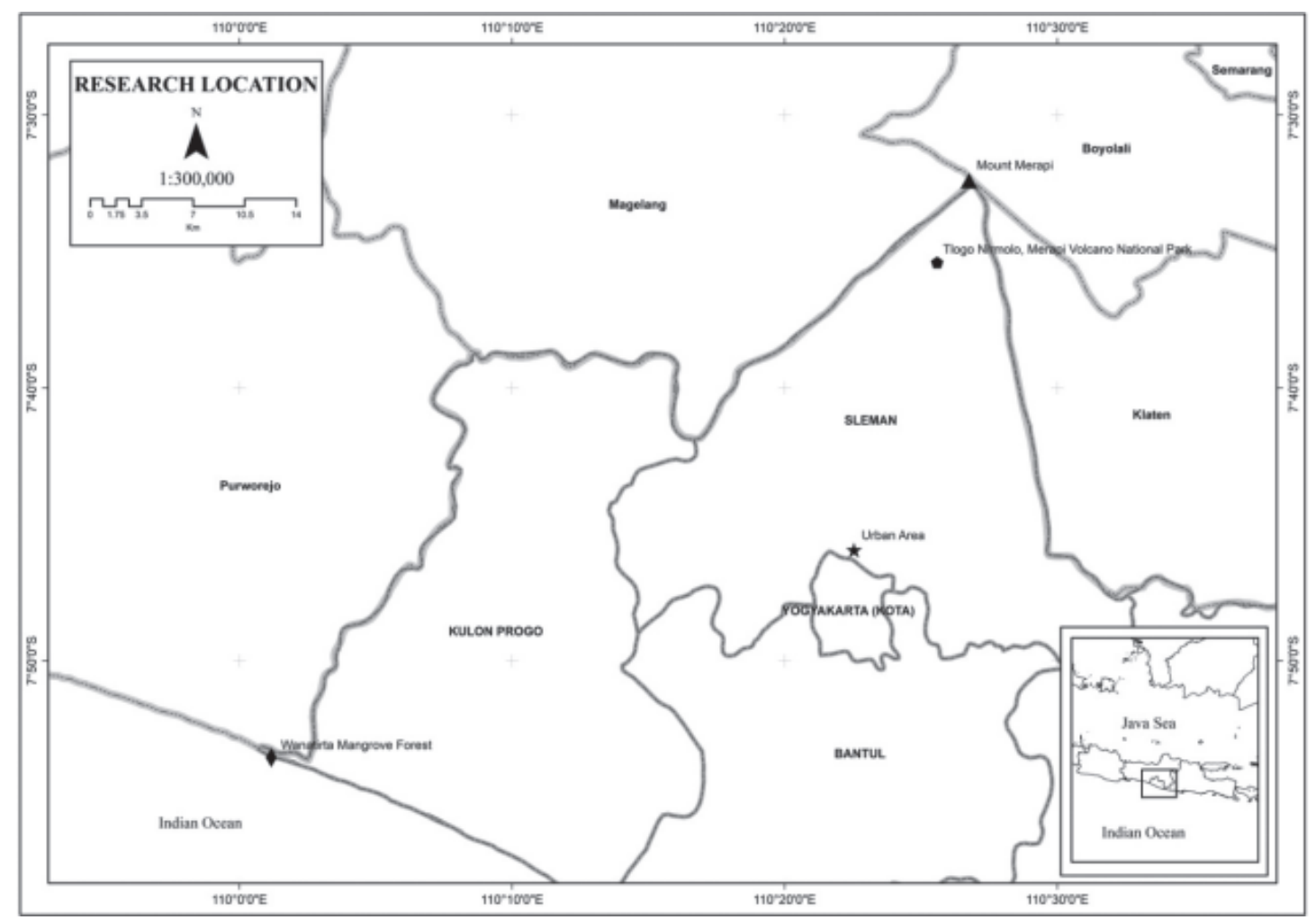

Fig. 1. Sampling site of this study. 


\section{Haematology analysis}

One $\mathrm{mL}$ whole blood sample of each bat was collected from the intracardiac and placed into a $1.5 \mathrm{~mL}$ microtube with anticoagulant EDTA. Bats were anesthetized and euthanized using Ketamine-Xylazine (50 mg/kg body weight). Total 20 parameters of complete blood counts, including erythrocyte, leukocyte, and platelet profiles were analyzed using Hematology Analyzer Sysmex XP-100.

Erythrocyte profile parameters consist of a number of the erythrocytes or red blood cell (RBC; 105/L), hemoglobin (HGB; g/dL), hematocrit (HCT; \%), mean corpuscular volume (MCV; fL), mean corpuscular hemoglobin $(\mathrm{MCH} ; \mathrm{pg})$, mean corpuscular hemoglobin concentration (MCHC; $\mathrm{g} / \mathrm{dL}$ ), red cell distribution width standard deviation (RDW-SD; fL) and red cell distribution width coefficient (RDW-CV; \%) counts.

Furthermore, parameters in leukocyte profile consist of leukocyte number of white blood cell (WBC; 103/mL), lymphocytes (\#LYM; 103/mL), neutrophils (\#NEUT; 103/mL), lymphocyte percentage per microliter blood (\%LYM; \%), neutrophil percentage per microliter blood (\%NEUT; $\%$ ), mixed number (\#MXD; $10^{3} / \mathrm{mL}$ ) and mixed percentage $(\% \mathrm{MXD} ; \%)$. Platelet profiles consists of platelet (PLT; $\left.10^{3} / \mathrm{mL}\right)$, platelet distribution width (PDW; fL), mean platelet volume (MPV; fL), platelet large cell ratio (P-LCR; \%) and platelet crit (PCT; \%). Blood smears were also used to verify if there are several mixed or not in the leukocyte profile.

\section{Statistical analysis}

Haematological measurements were tabulated and displayed as mean plus-minus standard deviation (SD) using the Microsoft Excel program (version 12.0, Microsoft ${ }^{\circledR}$ Excel $\left.\AA 2007\right)$. Normality test data were analyzed using the Shapiro-Wilk normality test within a 95\% confidence level. A Twosample t-test was used to determine whether the means between two categories based on sex (male and female), age (juvenile and adult), and habitat (urban and non-urban) are significantly different. The data that were not normally distributed were analyzed with the Mann-Whitney U test. All statistical analyses were performed using the PASTPaleontological statistics program, ver. 3.22 (Hammer et al., 2001).

The ratio number of erythrocytes to body weight and neutrophils to lymphocytes (NLR) were also calculated to find out the relation of health and stress levels of the bats (Wijayanti et al., 2011; Rahma et al., 2018). Animal use of this study was conducted under the Research Ethics Committee of the Faculty of Veterinary Medicine Universitas Gadjah Mada permit number 0108 / EC-FKH / Ex./ 2019.

\section{RESULTS}

A total of 31 individuals of Cynopterus spp. that collected from three sampling sites were used in this study, including ten adult male, ten adult female, four juvenile male and four juvenile female of $C$. brachyotis respectively, a juvenile male of $C$. minutus, a juvenile male $C$. tithaecheilus and an adult male $C$. sphinx. Because the number of $C$. brachyotis species was abundantly found and only one individual data of other Cynopterus spp. can be obtained, the statistical analysis was carried out for only C. brachyotis. Meanwhile, other species were used as comparative data.

\section{Erythrocyte profile}

\section{Erythrocytes (RBC) and hematocrit counts (HCT)}

Adult females of $C$. brachyotis showed the highest number of erythrocytes (RBC) and hematocrit counts (HCT) compared to other species in Cynopterus spp. (Table 1). Based on the Two-sample t-test, male and female $C$. brachyotis had no significant difference in $\operatorname{RBC}(p=0.396)$ as well as adult and juvenile $(p=0.121)$, and also between urban and non-urban $(p=0.396)$. HCT counts of $C$. brachyotis in sex, age, and habitat category were not normally distributed. Mann-Whitney U test showed that hematocrit counts between male and female $C$. brachyotis were not significantly different $(p=0.241)$. Furthermore, the juvenile and adult categories showed the same result ( $p=0.297)$, as well as urban and non-urban $(p=0.338)$.

\section{Hemoglobin value (HGB)}

Adult male $C$. sphinx showed the highest hemoglobin value (HGB) among Cynopterus spp. $(18.00 \mathrm{~g} / \mathrm{dL})$. Meanwhile, among $C$. brachyotis species, adult females have a higher HGB than male adults, juvenile males, and juvenile females (17.12 g/ dL). Normality test for HGB resulted that the data were not normally distributed for all categories. Mann-Whitney U test showed HGB of C. brachyotis were not significantly different between male and female ( $p=0.270)$, juvenile and adult $(p=0.492)$, also urban and non-urban $(p=0.291)$.

Mean corpuscular volume (MCV), mean corpuscular hemoglobin (MCH) and mean corpuscular hemoglobin concentration (MCHC)

The mean corpuscular volume (MCV) of adult male $C$. sphinx was the highest and $C$. tithaecheilus was the lowest among Cynopterus spp. in this study. The juvenile males of $C$. brachyotis have higher MCV compared to adult males, adult females, and juvenile females $C$. brachyotis. Along with increasing $\mathrm{MCV}$, mean corpuscular hemoglobin $(\mathrm{MCH})$ and mean corpuscular hemoglobin 
Table 1. Erythrocyte profile of four Cynopterus bat species in special region Yogyakarta. Indonesia, 2019

\begin{tabular}{|c|c|c|c|c|c|c|c|}
\hline & \multicolumn{4}{|c|}{ C.b } & \multirow{2}{*}{$\begin{array}{c}\text { C.m } \\
\text { Juvenile } \\
\text { Male } \\
(n=1)\end{array}$} & \multirow{2}{*}{$\begin{array}{c}\text { C.t } \\
\text { Juvenile } \\
\text { Male } \\
(n=1)\end{array}$} & \multirow{2}{*}{$\begin{array}{c}\text { C.s } \\
\text { Adult } \\
\text { Male } \\
(n=1)\end{array}$} \\
\hline & $\begin{array}{l}\text { Adult } \\
\text { Male } \\
(n=10)\end{array}$ & $\begin{array}{c}\text { Adult } \\
\text { Female } \\
(n=10)\end{array}$ & $\begin{array}{c}\text { Juvenile } \\
\text { Male } \\
(n=4)\end{array}$ & $\begin{array}{c}\text { Juvenile } \\
\text { Female } \\
(n=4)\end{array}$ & & & \\
\hline $\mathrm{RBC}\left(10^{5} / \mathrm{mL}\right)$ & $11.74 \pm 1.31$ & $12.17 \pm 0.86$ & $11.01 \pm 1.08$ & $11.32 \pm 1.20$ & 11.39 & 11.46 & 11.60 \\
\hline HGB (g/dL) & $16.60 \pm 2.58$ & $17.12 \pm 1.53$ & $15.98 \pm 1.78$ & $16.00 \pm 1.87$ & 16.70 & 17.48 & 18.00 \\
\hline HCT (\%) & $54.95 \pm 8.28$ & $57.26 \pm 4.85$ & $52.23 \pm 4.64$ & $53.33 \pm 5.61$ & 53.40 & 52.20 & 55.30 \\
\hline MCV (fL) & $46.75 \pm 3.27$ & $47.04 \pm 2.02$ & $47.48 \pm 0.80$ & $47.18 \pm 2.09$ & 46.90 & 45.50 & 47.70 \\
\hline $\mathrm{MCH}(\mathrm{pg})$ & $14.12 \pm 0.93$ & $14.06 \pm 0.71$ & $14.48 \pm 0.67$ & $14.10 \pm 0.51$ & 14.70 & 15.50 & 15.50 \\
\hline $\mathrm{MCHC}(\mathrm{g} / \mathrm{dL})$ & $30.20 \pm 1.11$ & $29.96 \pm 2.11$ & $30.58 \pm 1.75$ & $30.00 \pm 0.59$ & 31.30 & 34.10 & 32.50 \\
\hline RDW-SD (fL)* & $29.21 \pm 1.02$ & $29.60 \pm 3.76$ & $27.45 \pm 0.98$ & $27.43 \pm 1.42$ & 25.60 & 28.60 & 28.20 \\
\hline RDW-CV (\%) & $20.43 \pm 1.28$ & $19.24 \pm 1.04$ & $17.80 \pm 0.10$ & $18.60 \pm 0.90$ & 16.30 & 20.70 & 19.10 \\
\hline BW (g) & $38.09 \pm 6.12$ & $37.90 \pm 3.81$ & $26.63 \pm 2.15$ & $32.98 \pm 5.41$ & 22.30 & 59.60 & 84.70 \\
\hline
\end{tabular}

C.b: C. brachyotis, C.t: C.tithaecheilus, C.m: C. minutus, C.s: C. sphinx, Asterisk symbol indicates parameter that showed significantly different between juvenile and adult $C$. brachyotis $(p=0.035)$.

concentration $(\mathrm{MCHC})$ of these juvenile males were also higher than adult males, adult females, and juvenile females $C$. brachyotis (Table 1). Statistical analysis of MCV, MCH, and MCHC in C. brachyotis group using Two-sample t-test resulted no significant difference between female and male (MCV: $p=0.90$; MCH: $p=0.628$; MCHC: $p=0.595$ ), juvenile and adult (MCV: $p=0.689$; $\mathrm{MCH}: p=0.564$; MCHC: $=0.767)$, also between urban and non-urban (MCV: $p=0.610$; MCH: $p=0.299$; MCHC: $p=0.619$ ).

\section{Red cell distribution width (RDW)}

The highest red cell distribution width standard deviation (RDW-SD) among Cynopterus spp. showed by adult female $C$. brachyotis $(29.60 \mathrm{fL})$. While the juvenile males of $C$. tittacheilus showed the highest red cell distribution width coefficient (RDW-CV) counts (20.70\%). Mann-Whitney U test showed only RDW-SD counts between adult and juvenile $C$. brachyotis were significantly different $(p=0.035)$. The mean rank of adult individuals was higher than juvenile (10.708). Furthermore, RDW-CV counts of $C$. brachyotis between sex, age, and habitat category were showed no significant difference $(p=0.556$, $p=0.053$, and $p=0.389$, respectively).

Based on the ratio number of erythrocytes to body weight, juvenile males $C$. brachyotis shown the highest number $\left(0.42 \times 10^{5} \mu \mathrm{L} / \mathrm{g}\right)$ compared to adult males, adult females, and juvenile females of $C$. brachyotis. Whereas, juvenile male $C$. minutus was the highest among them $\left(0.51 \times 10^{5} \mu \mathrm{L} / \mathrm{g}\right)($ Table 4$)$.

\section{Leukocyte profile}

Leukocytes (WBC) and lymphocytes number (\#LYM)

The number of leukocytes (WBC) and lymphocytes (\#LYM) were high in adult males and juvenile males $C$. brachyotis $\left(11.62 \times 10^{3} / \mu \mathrm{L}\right.$ and
$6.58 \times 10^{3} / \mu \mathrm{L}$, respectively). However, adult male $C$. sphinx has the highest leukocytes and lymphocytes among Cynopterus spp. (Table 2). The number of leukocyte between urban and non-urban $C$. brachyotis were significantly different using MannWhitney $\mathrm{U}$ test $(p=0.016)$. The mean rank of nonurban $C$. brachyotis was higher than urban (10.611). Whereas, the leukocyte number between males and females also adults and juveniles showed different results ( $p=0.593$ and $p=0.803$, respectively). Hereinafter, based on the normality test, only lymphocyte numbers between urban and non-urban C. brachyotis were normally distributed. A twosample t-test showed that lymphocyte numbers of this category were not significantly different $(p=0.393)$, as well as sex and age category.

Neutrophils (\#NEUT), lymphocytes percentage (\%LYM), and neutrophil percentage (\%NEUT)

Adult males of $C$. brachyotis have the highest neutrophils compared to juvenile males, adult females, and juvenile females $\left(6.55 \times 10^{3} / \mu \mathrm{L}\right)$. A juvenile male $C$. tithaecheilus showed the lowest neutrophils number within Cynopetrus spp. $(0.80 \times$ $\left.10^{3} / \mu \mathrm{L}\right)$. Mann-Whitney $\mathrm{U}$ test revealed that there is no significant difference in neutrophils number between sex $(p=0.789)$, age $(p=0.406)$, and habitat category $(p=0.067)$.

Juvenile males $C$. brachyotis showed the highest lymphocytes percentage within this species (69.18\%), while adult males showed the highest neutrophil percentage (49.98\%). However, both lymphocytes and neutrophils percentage between juvenile and adult were not significantly different using the Mann-Whitney U test $(p=0.306)$.

All leukocyte profiles of Cynopterus spp. individuals were not shown mixed numbers (Table 2). A blood smear of $C$. brachyotis did not show 
Table 2. Leukocyte profile of four Cynopterus bat species in special region Yogyakarta. Indonesia, 2019

\begin{tabular}{|c|c|c|c|c|c|c|c|}
\hline & \multicolumn{4}{|c|}{ C.b } & \multirow{2}{*}{$\begin{array}{c}\text { C.m } \\
\text { Juvenile } \\
\text { Male } \\
(n=1)\end{array}$} & \multirow{2}{*}{$\begin{array}{c}\text { C.t } \\
\text { Juvenile } \\
\text { Male } \\
(n=1)\end{array}$} & \multirow{2}{*}{$\begin{array}{c}\text { C.s } \\
\text { Adult } \\
\text { Male } \\
(n=1)\end{array}$} \\
\hline & $\begin{array}{l}\text { Adult } \\
\text { Male } \\
(n=10)\end{array}$ & $\begin{array}{c}\text { Adult } \\
\text { Female } \\
(n=10)\end{array}$ & $\begin{array}{c}\text { Juvenile } \\
\text { Male } \\
(n=4)\end{array}$ & $\begin{array}{c}\text { Juvenile } \\
\text { Female } \\
(n=4)\end{array}$ & & & \\
\hline WBC $\left(10^{3} / \mathrm{mL}\right)^{*}$ & $11.62 \pm 10.23$ & $10.90 \pm 8.21$ & $10.08 \pm 3.15$ & $6.47 \pm 0.78$ & - & 4.00 & 22.30 \\
\hline \#LYM (103/mL) & $5.07 \pm 4.71$ & $4.97 \pm 3.43$ & $6.58 \pm 1.68$ & $4.03 \pm 0.78$ & - & 3.20 & 21.10 \\
\hline \#NEUT (103/mL) & $6.55 \pm 6.95$ & $5.93 \pm 7.21$ & $3.50 \pm 3.30$ & $2.43 \pm 1.30$ & - & 0.80 & - \\
\hline \%LYM (\%) & $50.02 \pm 31.07$ & $55.79 \pm 28.39$ & $69.18 \pm 21.77$ & $63.53 \pm 18.30$ & - & 79.30 & 94.80 \\
\hline \%MXD (\%) & - & - & - & - & - & - & - \\
\hline \%NEUT (\%) & $49.98 \pm 31.07$ & $44.21 \pm 28.39$ & $30.83 \pm 21.77$ & $36.47 \pm 18.30$ & - & 20.70 & - \\
\hline \#MXD $\left(10^{3} / \mathrm{mL}\right)$ & - & - & - & - & - & - & - \\
\hline BW (g) & $38.09 \pm 6.12$ & $37.90 \pm 3.81$ & $26.63 \pm 2.15$ & $32.98 \pm 5.41$ & 22.30 & 59.60 & 84.70 \\
\hline
\end{tabular}

C.b: C. brachyotis, C.t: C.tithaecheilus, C.m: C. minutus, C.s: C. sphinx, Asterisk symbol indicates parameter that showed significantly different between urban and non-urban $C$. brachyotis $(p=0.016)$.

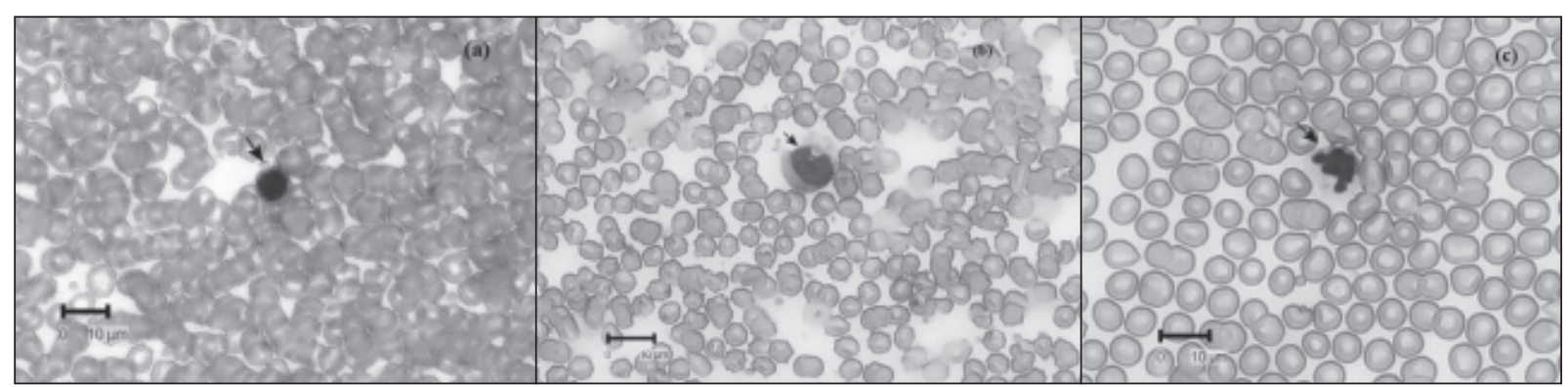

Fig. 2. Blood smear of Cynopterus brachyotis, including (a) lymphocyte, (b) monocyte, (c) neutrophil (pointed with the arrow, scale bar $10 \mu \mathrm{m})$.

Table 3. Platelet profile of four Cynopterus bat species in special region Yogyakarta. Indonesia, 2019

\begin{tabular}{|c|c|c|c|c|c|c|c|}
\hline & \multicolumn{4}{|c|}{ C. $b$} & \multirow{2}{*}{$\begin{array}{c}\text { C.m } \\
\text { Juvenile } \\
\text { Male } \\
(n=1)\end{array}$} & \multirow{2}{*}{$\begin{array}{c}\text { C.t } \\
\text { Juvenile } \\
\text { Male } \\
(n=1)\end{array}$} & \multirow{2}{*}{$\begin{array}{c}\text { C.s } \\
\text { Adult } \\
\text { Male } \\
(n=1)\end{array}$} \\
\hline & $\begin{array}{l}\text { Adult } \\
\text { Male } \\
(n=10)\end{array}$ & $\begin{array}{c}\text { Adult } \\
\text { Female } \\
(n=10)\end{array}$ & $\begin{array}{c}\text { Juvenile } \\
\text { Male } \\
(n=4)\end{array}$ & $\begin{array}{c}\text { Juvenile } \\
\text { Female } \\
(n=4)\end{array}$ & & & \\
\hline $\operatorname{PLT}\left(10^{3} / \mathrm{mL}\right)^{*}$ & $\begin{array}{c}507.50 \pm \\
139.02\end{array}$ & $\begin{array}{c}321.33 \pm \\
167.13\end{array}$ & $\begin{array}{c}266.33 \pm \\
117.17\end{array}$ & $\begin{array}{c}676.00 \pm \\
263.00\end{array}$ & 314.00 & ++++ & 228.00 \\
\hline PDW (fL) & $20.75 \pm 9.65$ & - & $18.85 \pm 8.25$ & $10.30 \pm 0.00$ & - & - & - \\
\hline MPV (fL) & $7.00 \pm 0.40$ & - & $6.85 \pm 0.15$ & $7.20 \pm 0.00$ & - & - & - \\
\hline P-LCR (\%) & $6.29 \pm 3.31$ & - & $5.55 \pm 1.75$ & $7.00 \pm 0.00$ & - & - & - \\
\hline РCT (\%) & $0.40 \pm 0.04$ & - & $0.23 \pm 0.08$ & $0.68 \pm 0.00$ & - & - & \\
\hline BW (g) & $38.09 \pm 6.12$ & $37.90 \pm 3.81$ & $26.63 \pm 2.15$ & $32.98 \pm 5.41$ & 22.30 & 59.60 & 84.70 \\
\hline
\end{tabular}

C.b: C. brachyotis, C.t: C.tithaecheilus, C.m: C. minutus, C.s: C. sphinx, Asterisk symbol indicates parameter that showed significantly different between urban and non-urban $C$. brachyotis $(p=0.021)$.

abnormality of lymphocyte, monocyte, and neutrophil. It is indicated that there is no mix (Figure 2). Adult females of $C$. brachyotis showed the highest number of neutrophil to lymphocyte ratio (NLR) compared to other species $\left(1.05 \times 10^{3} / \mathrm{mL}\right)$ (Table 4$)$.

\section{Platelet profile}

Juvenile females of $C$. brachyotis have the highest platelet counts $\left(676 \times 10^{3} / \mu \mathrm{L}\right)$. Meanwhile, platelets of juvenile male $C$. tithaecheilus exceeded the maximum value of the hematology analyzer (indicated by the plus symbol) (Table 3). Platelet counts between urban and non-urban $C$. brachyotis were significantly different using the Two-sample t-test $(p=0.021)$. The mean value of non-urban individuals was higher than urban (513.56). Whereas, platelet counts between sex and age category were not significant ( $p=0.201$ and $p=0.987$, respectively). 
Table 4. Haematological profile ratio of four Cynopterus species from Sleman district, Tlogo Nirmolo Merapi volcano national park, and Wanatirta mangrove forest, special region Yogyakarta. Indonesia, 2019

\begin{tabular}{|c|c|c|c|c|c|c|c|}
\hline \multirow[b]{2}{*}{ Parameter } & \multicolumn{4}{|c|}{ C.b } & \multirow{2}{*}{$\begin{array}{c}\text { C.m } \\
\text { Juvenile } \\
\text { Male } \\
(n=1)\end{array}$} & \multirow{2}{*}{$\begin{array}{c}\text { C.t } \\
\text { Juvenile } \\
\text { Male } \\
(n=1)\end{array}$} & \multirow{2}{*}{$\begin{array}{l}\text { C.s } \\
\text { Adult } \\
\text { Male } \\
(\mathrm{n}=1)\end{array}$} \\
\hline & $\begin{array}{l}\text { Adult } \\
\text { Male } \\
(n=10)\end{array}$ & $\begin{array}{l}\text { Adult } \\
\text { Female } \\
(n=10)\end{array}$ & $\begin{array}{c}\text { Juvenile } \\
\text { Male } \\
(n=4)\end{array}$ & $\begin{array}{c}\text { Juvenile } \\
\text { Female } \\
(n=4)\end{array}$ & & & \\
\hline RBC/BW (105mL/g) & $0.31 \pm 0.05$ & $0.33 \pm 0.05$ & $0.42 \pm 0.05$ & $0.35 \pm 0.07$ & 0.51 & 0.19 & 0.14 \\
\hline NEUT/LYM $\left(10^{3} / \mathrm{mL}\right)$ & $0.84 \pm 0.75$ & $1.05 \pm 1.31$ & $0.61 \pm 0.54$ & $0.68 \pm 0.43$ & - & 0.25 & 0.06 \\
\hline
\end{tabular}

C.b: C. brachyotis, C.t: C.tithaecheilus, C.m: C. minutus, C.s: C. sphinx.

\section{DISCUSSION}

\section{Erythrocyte profile}

Erythrocytes, hemoglobin, hematocrit, leukocytes, and platelet counts of male animals are mostly higher than female. This is commonly found in mammals such as rats and mice (Wolford et al., 1986; Smith et al., 1994) and also in fruit bat C. tithaecheilus, but not significant (Rahma et al., 2017). Nevertheless, this study indicates otherwise.

A similar condition occurs in wild-caught Rousettus aegyptiacus. Erythrocytes, hematocrit, and hemoglobin counts of female $R$. aegyptiacus from orchard habitat is higher than the male which is taken from the cave (Van der Westhuyzen, 1988). Meanwhile, it has also happened in Wistar rats (Rattus norvegicus Berkenhout, 1769) under laboratory conditions (Fitria \& Sarto, 2014). Van der Westhuyzen (1988) also showed that male $R$. aegyptiacus in captivity has higher erythrocyte, hematocrit, and hemoglobin rather than females. However, another Rousettus species, namely $R$. amplexicaudatus has lower erythrocyte and hemoglobin than females in captivity (Husni Mubarok, unpublished).

Environmental conditions such as temperature, humidity, and oxygen level can affect the erythrocyte profile in bats. In this study, the temperature ranged from $21.8^{\circ} \mathrm{C}$ to $29.8^{\circ} \mathrm{C}$, and humidity ranging from $70 \%$ to $90 \%$. In this study, the number of erythrocytes (RBC) of C. brachyotis ranged from 11.01 to $12.17 \times$ $10^{5} / \mu \mathrm{L}$, hemoglobin (HGB) from 15.98 to $17.12 \mathrm{~g} / \mathrm{dL}$, leukocytes 6.48 to $11.62 \times 10^{3} / \mu \mathrm{L}$, and platelets of C. brachyotis ranged from 266.33 to $676.00 \times 10^{3} / \mu \mathrm{L}$. However, Wijayanti et al. (2011) found that erythrocytes number (RBC) of C. brachyotis which inhabit cave habitats is relatively higher $(13.2 \pm 0.9$ $\times 10^{5} / \mu \mathrm{L}$ ), with a temperature of $27.2^{\circ} \mathrm{C}$ and humidity of $52.8 \%$. The difference condition between the microclimate factor of the cave and the environmental factor of the sampling location in this study is suspected to cause its different result.

The number of erythrocytes and hemoglobin is increasing along with age in Pteropus alecto (Smith et al., 1994). Erythrocyte, hemoglobin, and hematocrit counts of captive $P$. alecto in the younger age category are lower compared to an adult. It is increasing in different stages of age, from juveniles to adults (McMichael et al., 2015). This study shows a different result. There is no significant difference in erythrocyte, hemoglobin, and hematocrit counts between juvenile and adult $C$. brachyotis. This condition is suspected influenced by other factors such as environmental conditions. High humidity, low temperature, and low oxygen level can also affect the high concentration of bats hemoglobin (Wijayanti et al., 2011). Flight activity and habitat type conditions also affect the hemoglobin profile of fruit bats (Saimina et al., 2019). Bats have high levels of hemoglobin compared to other terrestrial mammals. It is because vascular permeability changes due to environmental temperature and flight activity (Arévalo et al., 1991; Arad \& Korine, 1993). Unfortunately, it needs further analysis in this study.

The lowest MCV in this study showed by $C$. tithaecheilus $(45.50 \mathrm{fL})$. This value was relatively higher with a previous study, as well as $\mathrm{MCH}$ and MCHC (Rahma et al., 2018). Adult individuals of $P$. alecto have higher MCHC compared to juveniles (McMichael et al., 2015). However, MCV, MCH, and $\mathrm{MCHC}$ values of $C$. brachyotis were not significant differences between sex, age, and habitat categories. The haematology profile of fruit bats Eidolon helvum was shown the same result. MCV and MCHC of E. Helvum were not significantly different between males and females (Balthazary et al., 2007).

The result showed a significant difference for RDW-SD counts between adult and juvenile $C$. brachyotis. In human, red blood cell distribution width (RDW) of individuals were strongly associated with age, but not with gender. Moreover, rather than being connected to a particular form of haematology analyzer, this age-dependency of RDW was a universal biological feature. RDW-SD is also known as a potential marker in many clinical conditions (Hoffmann et al., 2015).

Juvenile males of $C$. brachyotis in this study also have a high ratio of erythrocytes to body weight. The difference ratio number of erythrocytes or hemoglobin to body weight is strongly influenced 
by environmental conditions such as temperature, humidity, oxygen percentage, and ammonia levels (Wijayanti et al., 2011). The erythrocyte profile of Cynopterus spp., especially C. brachyotis in the study was not related to the sex category. This condition is in line with the erythrocyte profile study of fruit bats Epomops franqueti, which did not show significant differences related to sex (Ekeolu \& Adebiyi, 2018).

\section{Leukocyte profile}

Leukocyte profile has been used to study defense systems in animals, including stress levels. In contrast to erythrocytes, the total number of leukocytes, neutrophils, lymphocytes, and platelets will be decreasing along with age, such as in rats and mice (Smith et al., 1994). However, several studies showed that juvenile fruit bats $C$. titthaecheilus (Rahma et al., 2018), P. alecto (McMichael et al., 2015), and $P$. giganteus (Mclaughlin et al., 2007) have high leukocyte and lymphocyte counts. In this study, leukocyte numbers (WBC) between juvenile and adult $C$. brachyotis were not significantly different. Interestingly, leukocytes of urban and non-urban $C$. brachyotis showed a significant difference in which non-urban bats have a higher mean rank. However, fruit bats $E$. franqueti from the urban areas were reported to have very high leukocyte numbers (Ekeolu \& Adebiyi, 2018). Higher leukocyte numbers may provide information about conditions of an animal's immune system such as infection or inflammation (Ekeolu \& Adebiyi, 2018).

Lymphocytes and neutrophils percentage of C. brachyotis in this study were not significant differences between sex, age, and habitat. The study showed that lymphocyte percentage in wild-caught juvenile $P$. giganteus is significantly different from the adult. High lymphocytes in juvenile animals can be caused by immune system stimulation which is a natural response during the capture process (Mclaughlin et al., 2007).

The ratio number between neutrophils and lymphocytes (NLR) can be used as an index of animal stress. A higher neutrophil value compared to lymphocytes is an indicator to predict animals are under stress conditions (Rahma et al., 2018). Adult females $C$. brachyotis in this study showed higher NLR, but generally, neutrophils were lower than lymphocytes in each age category. This indicates that all animals used in this study had low stress levels. Female bats are thought to be more responsive to environmental stresses, while male bats are more stable (Rahma et al., 2018). Juvenile C. brachyotis also showed lower stress index values. This is presumably that juvenile bats face fewer illnesses and have not yet done intercourse or copulation, as well as $C$. titthaecheilus bats.

\section{Platelet profile}

Platelets play important role in the blood clotting process. The highest platelet count of C. brachyotis in this study was shown by juvenile females. Female $P$. alecto is known to have a greater platelet count than males (Mclaughlin et al., 2007). Furthermore, juvenile $C$. titthaecheilus are also known to have more platelet counts than adults, but female individuals have lower values than males (Rahma et al., 2018). Platelet counts are strongly influenced by age, sex, genetic, seasonal, and pre-analytical factors (Rashid et al., 2016). However, in this study, only platelet counts between urban and non-urban C. brachyotis showed a significant difference. It can be suspected that the platelet numbers of this species were affected by environmental factors such as seasonal, pre-analytical, and habitat, but still need to be analyzed further.

\section{CONCLUSION}

There is no significant difference in erythrocyte, hemoglobin, and hematocrit counts between sex, age, and habitat categories of $C$. brachyotis. However, RDW-SD counts between juvenile and adult $C$. brachyotis were significantly different. Red blood cell distribution width (RDW) is regarded to have a strong association with the age stage. Leukocyte numbers (WBC) and platelet count C. brachyotis showed a significant difference between urban and non-urban. This is suspected to be affected by environmental factors. This research needs to be continued by increasing the number of samples. The correlation of haematological profile to seasonal change needs to be done for further research.

\section{ETHICS APPROVAL}

The study was approved by the Research Ethics Committee of the Faculty of Veterinary Medicine Universitas Gadjah Mada (Ethical approval number: 0108 / EC-FKH/ Ex./ 2019)

\section{ACKNOWLEDGEMENTS}

We acknowledge Rekognisi Tugas Akhir funding number 2488/UN1.P.III/DIT-LIT/PT/2020 from Universitas Gadjah Mada and Ph.D. scholarship from the Ministry of Religious Affairs for the first author. We are also indebted to The Head of the Animal Physiology Laboratory, Faculty of Biology, Universitas Gadjah Mada for providing research facilities. 


\section{REFERENCES}

Arad, Z. \& Korine, C. 1993. Effect of water restriction on energy and water balance and osmoregulation of the fruit bat Rousettus aegyptiacus. Journal of Comparative Physiology B, 163(5): 401-5.

Arévalo, F., Perez-Suarez, G. \& Lóapez-Luna, P. 1991. Oxygen-binding properties of bat hemoglobins. Archives Internationales de Physiologie, de Biochimie et de Biophysique, 99(1): 77-81.

Balthazary, S.T., Max, R.A., Mlay, E., Shayo, G., Mlay, P. \& Phiri, E.C. 2007. Some haematological, biochemical and zootechnical parameters of fruit eating bat (Eidolon helvum) in Morogoro Tanzania. Tanzania Veterinary Journal, 24(2): 129-138.

Burgin, C.J., Wilson, D.E., Mittermeier, R.A., Rylands, A.B., Lacher, T.E., Sechrest, W. 2020. Illustrated Checklist of The Mammals of The World. Spain. 1166 pp.

Campbell, P., Schneider, C.J., Adnan, A.M., Zubaid, A. \& Kunz, T.H. 2004. Phylogeny and phylogeography of Old World fruit bats in the Cynopterus brachyotis complex. Molecular Phylogenetics and Evolution, 33(3): 764-81.

Corbet, G.B. \& Hill, J.E. 1992. The mammals of the Indomalayan region: a systematic review. Oxford University Press, UK. 488 pp.

Ekeolu, O.K. \& Adebiyi, O.E. 2018. Hematology and erythrocyte osmotic fragility of the Franquet's fruit bat (Epomops franqueti). Journal of Basic and Clinical Physiology and Pharmacology, 29(4): 391-394.

Fitria, L. \& Sarto, M. 2014. Profil hematologi tikus (Rattus norvegicus Berkenhout, 1769) galur wistar jantan dan betina umur 4, 6, dan 8 minggu. Biogenesis: Jurnal Ilmiah Biologi, 2(2): 94-100.

Gulland, F.M.D. \& Hawkey, C. 1990. Avian hematology. Veterinary Annual, 30: 126-136.

Hall, J., Rose, K., Smith, C., De Jong, C., Phalen, D., Austen, J. \& Field, H. 2014. Health assessment of the Christmas Island flying fox (Pteropus melanotus natalis). Journal of Wildlife Diseases, 50(3): 447-458.

Hammer, Ø., Harper, D.A. \& Ryan, P.D. 2001. PAST: Paleontological statistics software package for education and data analysis. Palaeontologia Electronica, 4(1): 1-9.

Hoffmann, J.J., Nabbe, K.C. \& van den Broek, N.M. 2015. Effect of age and gender on reference intervals of red blood cell distribution width (RDW) and mean red cell volume (MCV). Clinical Chemistry and Laboratory Medicine (CCLM), 53(12): 2015-2019.
Hossain, M.B., Islam, M.N., Shaikat, A.H., Yasin, M.G., Hassan, M.M., Islam, S.K.M.A., Rahman, A., Mamun, M.A. \& Khan, S.A. 2013. Biochemical profile of wild-captured Indian flying fox (Pteropus giganteus) in Bangladesh. Bangladesh Journal of Veterinary Medicine, 11(1): 75-79.

Huang, J.C.C., Ariyanti, E.S., Rustiati, E.L., Daaras, K., Maryanto, I., Maharadatunkamsi, Meyner, N., Kingston, T. \& Wiantoro, S. 2016. Kunci identifikasi kelelawar di Sumatera: dengan catatan hasil perjumpaan di kawasan Bukit Barisan Selatan [WWW Document]. URL http://www. seabcru.org/ (accessed 10.16.19).

Kartono, A.P., Prayogi, K.D. \& Maryanto, I. 2017. Keanekaragaman jenis kelelawar di Hutan Pendidikan Gunung Walat Sukabumi Jawa Barat. Zoo Indonesia, 26(1): 33-43.

Maryanto, I. 1993. Aktivitas kelelawar pemencar biji (Cynopterus brachyotis) dalam memanfaatkan buah-buahan masak di kawasan DAS Hulu Cisadane. Zoo Indonesia, 17: 1-7.

Maryati, M., Kartono, A.P. \& Maryanto, I. 2008. Kelelawar pemakan buah sebagai polinator yang diidentifikasi melalui polen yang digunakan sebagai sumber pakannya di kawasan Sektor Linggarjati, Taman Nasional Ciremai Jawa Barat. Jurnal Biologi Indonesia, 4(5): 335-347.

McLaughlin, A.B., Epstein, J.H., Prakash, V., Smith, C.S., Daszak, P., Field, H.E. \& Cunningham, A.A. 2007. Plasma biochemistry and hematologic values for wild-caught flying foxes (Pteropus giganteus) in India. Journal of Zoo and Wildlife Medicine, 38(3): 446-452.

McMichael, L., Edson, D., McLaughlin, A., Mayer, D., Kopp, S., Meers, J. \& Field, H. 2015. Haematology and plasma biochemistry of wild black flying-foxes (Pteropus alecto) in Queensland, Australia. PLoS ONE, 10(5): 1-13.

Mickleburgh, S.P., Hutson, A.M. \& Racey, P.A. 1992. Old World fruit bats. An action plan for their conservation. IUCN, Switzerland. 263 pp.

Rahma, A., Hanadhita, D., Cahyadi, D.D., Supratikno, S., Maheshwari, H., Satyaningtijas, A.S. \& Agungpriyono, S. 2017. Haematological study of fruit bat, Cynopterus tithaecheilus, in: $1 \mathrm{st}$ International Conference in One Health $(\mathrm{ICOH}$ 2017). Atlantis Press, pp 164-168.

Rahma, A., Hanadhita, D., Prawira, A.Y., Cahyadi, D.D., Supratikno, H.M., Satyaningtijas, A.S. \& Agungpriyono, S. 2018. Indentifikasi tingkat kesehatan dan stres kelelawar pemakan buah (Cynopterus titthaecheilus). Jurnal Veteriner, 19(4): 460-466. 
Rashid, N., Irfan, M., Nadeem, M.S. \& Shabbir, A. 2016. Comparative seasonal haematology of two bat species, Scotophilus heathii and Pipistrellus pipistrellus, in a subtropical area of Pakistan. Pakistan Journal of Zoology, 48(5): 1503-1510.

Saimina, A.J., de Queljoe, E. \& Lengkong, H.J. 2019. Deskripsi hematologi kelelawar di gunung Tangkoko berdasarkan pemeriksaan darah lengkap. PHARMACON, 8(3): 243-251.

Simmons, N.B. \& Cirranello, A.L. 2020. Bat species of the world: a taxonomic and geographic database [WWW Document]. URL https:// batnames.org/ (accessed 3.30.21).

Smith, C.A., Andrews, C.M., Collard, J.K., Hall, D.E. \& Walker, A.K. 1994. Rats and Mouse. In: Color atlas of comparative diagnostic \& experimental hematology. Smith CA, et al. (Eds.). Wolfe Publishing, Barcelona. pp. 9-15.

Soegiharto, S., Kartono, A.P. \& Maryanto, I. 2010. Pengelompokan kelelawar pemakan buah dan nektar berdasarkan karakteristik jenis pakan polen di Kebun Raya Bogor, Indonesia. Jurnal Biologi Indonesia, 6(2): 225-235.
Suyanto, A. 2001. Kelelawar di Indonesia. Puslitbang Biologi - LIPI, Bogor. 126 pp.

Van der Westhuyzen, J. 1988. Haematology and iron status of the Egyptian fruit bat, Rousettus aegyptiacus. Comparative Biochemistry and Physiology Part A: Physiology, 90(1): 117-120.

Wijayanti, F., Solihin, D.D., Alikodra, H.S. \& Maryanto, I. 2011. Eritrosit dan hemoglobin pada kelelawar gua di kawasan karst Gombong, Kebumen, Jawa Tengah. Jurnal Biologi Indonesia, 7(1): 89-98.

Wolford, S.T., Schroer, R.A., Gohs, F.X., Gallo, P.P., Brodeck, M., Falk, H.B. \& Ruhren, R. 1986. Reference range data base for serum chemistry and hematology values in laboratory animals. Journal of Toxicology and Environmental Health, 18(2): 161-188. 
